\title{
Methodological guidelines for optimizing the interaction between landscape architecture and urban planning
}

\author{
Vaiva Deveikienè, Vilnius Gediminas Technical University
}

\begin{abstract}
The article presents the results of research on optimization of interaction between natural and urban structures by applying the principles of landscape architecture. The research seeks to answer how landscape architecture can be beneficial in pursuit for the sustainable coexistence of nature and the city, what forms the creative field of landscape architecture in the urban environment and what determines the optimal expression of landscape architectural means in the urban landscape. The research is carried out in the city of Vilnius (Lithuania), but methods of the problem analysis and research can be easily adapted to other cities. The hypothesis of the research states that landscape architecture is an integral part of sustainable urban development and urban design paradigm, while applying the methods and principles of creation of landscape architecture, city's ecological, aesthetic and socio-functional needs are optimally matched and solved by combining them into a unified, sustainable three-member system operating in time and generating continuous natural and social processes. The article presents the conclusions of the research results concerning the factors determining the quality and specifics of interaction between landscape architecture and urbanism, in respect of optimal methods of interaction research, expression indicators and evaluation criteria.
\end{abstract}

Keywords: landscape architecture, interaction of natural and urban structures, ecological ethics, three-dimensional assessment system

\section{Introduction}

The global practice shows that cities, since the very beginning of establishment and in particular during their growth and expansion in the second half of the 19th century, not only addressed the construction tasks of streets and buildings but also sought for the actual relationship with nature, by adapting, mimicking it, embedding it into the urban fabric, creating deliberately to only improve the lives of people in the city.

The history of urbanism has been changing philosophers, theories, styles and priorities, and in this particular change we can see the development of landscape architecture, theoretical and practical virages, the growth of its role and new opportunities to contribute to the development of an urban landscape, in addressing the complex challenges of a sustainable green city. In the contemporary world of science and practice, the landscape architecture's area of expertise includes increasingly complex tasks related to the city management, renewal and development. City planners, urbanist and landscape researchers agree on a number of emerging interdisciplinary issues, as the city is a multifunctional organism undoubtedly having human well-being needs as its centrepiece. A new approach to landscape architecture and urbanization is demonstrated by the US researchers Ch. Waldheim, M. Mostafavi, J. Corner and others $[22 ; 6 ; 30 ; 31]$ who created a new paradigm of landscape urbanism. The role and importance of landscape architecture in sustainable urban

processes was studied by French scientists H. Soulier (2006); C. Abaut-de Chastene [1]; N. Bchir Jaber [2]; F.A Leger-Smith [14]. Application of the principles and methods of landscape architecture in architecture was demonstrated by D. Jauslin (2010) in his dissertation "Architecture with landscape methods" [13].

In Lithuania, the essence and significance of landscape architecture is not yet unanimously understood at theoretical level or in professional activities. Both the public and planning and design specialists have very different approaches to the competences of landscape architecture and the field of creative activities. There is a gap between landscape architecture and urbanism, and building architectural solutions, often failing to understand the role of cooperation, denying or ignoring each other. This exclusion problem begins at the level of urban planning and strategy setting and moves to the levels of block and object planning and design. Due to this gap, the issues of integration of the city's natural frame and green areas become problematic, deteriorating the quality of recreation and everyday environment, extenuating architectural solutions of engineering infrastructure and even social infrastructure.

The aim of the research is to create a methodological model for optimizing the interaction between landscape architecture and urbanism, based on sustainability principles. The problems of modern cities testify to the need to 
strengthen the integration of landscape architecture and other urban processes, however, it is still not clear what determines the optimal interaction between landscape architecture and urbanism ideas, theories, activities and solutions, and how to achieve this synergy. The research seeks to substantiate or prove that landscape architecture is an integral part of sustainable urban development and part of the urban design paradigm, but the nature and extent of tasks assigned to it depends on the level of the managed territory, priorities and program. One of the hypotheses maintains that with proper presentation of landscape architecture in urban processes, priorities for landscape conservation and management are timely set, natural and anthropogenic resources are rationally preserved and optimally used and creatively adapted for the needs of people. Applying creative methods and principles of landscape architecture, the ecological, aesthetic and social needs of the city are optimally matched and addressed by combining them into a united, sustainable three-dimensional system that operates in time and generates ongoing natural and social processes.

The problem of research of the relation between the city and nature is inseparable from the problems of landscape research in general, related to such features of today's landscapes as rapid changes and their large scale, increasing complexity of landscapes, fragmentation both in the physical, visual, and ecological sense, and also due to the intersecting and not always visible social, cultural, economic and other interests [10]. In the 21st century, science is looking for ways to integrate the methods and conclusions of various fields of science, focusing in particular on the landscape and its management, as an alternative way and approach to addressing the issues of sustainable city, taking into account the abundance and integrity of the services provided by the landscape. Compared to other design and planning processes, landscape methods integrate environmental processes and identify beneficial synergies [23]. Lithuanian scientists speak in detail about the complexity of landscape research, arguing that the landscape is the area of interest of many sciences and professions. Landscape assessment and perception problems are addressed by philosophy, sociology, environmental psychology, geography, ecology, etc. Each field of science contributes to the landscape research with its own point of view and methods [35]. The aim of the article is to discuss the results of the research and to present conclusions.

\section{Materials and Methods}

The issues of aesthetic effects of landscape and its evaluation were studied, and a number of methods and criteria were proposed by scientists $\mathrm{S}$.
Kaplan [18], A. Stamps III [26]; A. Ode, M. S. Tveit and G. Fry [24]; A. Berleant [3]; D. J. Stobbelaar ir B. Pedroli [27]; A. Brink and D. Bruns [4]; R. van Etteger, I. H. Thompson ir V. Vicenzotti [9] and others. Landscape aesthetics and ecology issues were analyzed by J. I. Nassauer [23]; Latvian scholars M. Jankevica [11, 12]; M. Veinberga and D. Zigmunde [32]. However, most of the research is directed towards the landscape in the general sense, which is examined without reference to the landscape architecture, or only analysing the objects of landscape architecture, examining them separately in the ecological, aesthetic-ecological aspects. The social aspect is most often encountered in researching the problems of public spaces. The issue of compatibility of aesthetics, ecology and social aspects was raised by I. Thompson [29], treating it rather as an ethical problem and leaving the question of this compatibility between the three aspects open [29].

In our opinion, it is equally important to understand and appreciate the interaction between pure ecological functions and compositional structural elements that represent aesthetic categories, while the process of their optimal interaction is essentially a creative process of landscape architecture, with predefined methods and agreed criteria. The social criteria group is inevitably connected to the ecological and aesthetic criteria groups. The novelty of the research is determined by the fact that it analyses the interaction between natural and urban structures, where optimization possibilities are defined through the prism of the landscape architecture, and the research is carried out using a sustainability-based, three-member system of criteria, evaluating the interaction in the defined theories equally from the environmental, social and aesthetical aspects.

The main natural elements forming the city - the terrain; water bodies and vegetation - are analyzed in relation to the elements of perception of the urban structure - paths, nodes, edges, landmarks, districts, which are selected by adapting the method of $\mathrm{K}$. Lynch [16], that has recently been increasingly used in the landscape architectural research [2]. In terms of landscape architecture, all five elements are important, but the edges, paths and nodes should be distinguished in particular. Edges essentially form spaces, providing them a contour, shape, and character; the path is an important compositional element organise involve the city life and cognition of landscape; nodes are well-arranged spaces concentrated in themselves, or the stepping stone for an overview of the surroundings.

The system of evaluation criteria was based on the methods of selective analysis of scientific literature and Delphi survey of experts. Statistical information and monitoring methods were used to 


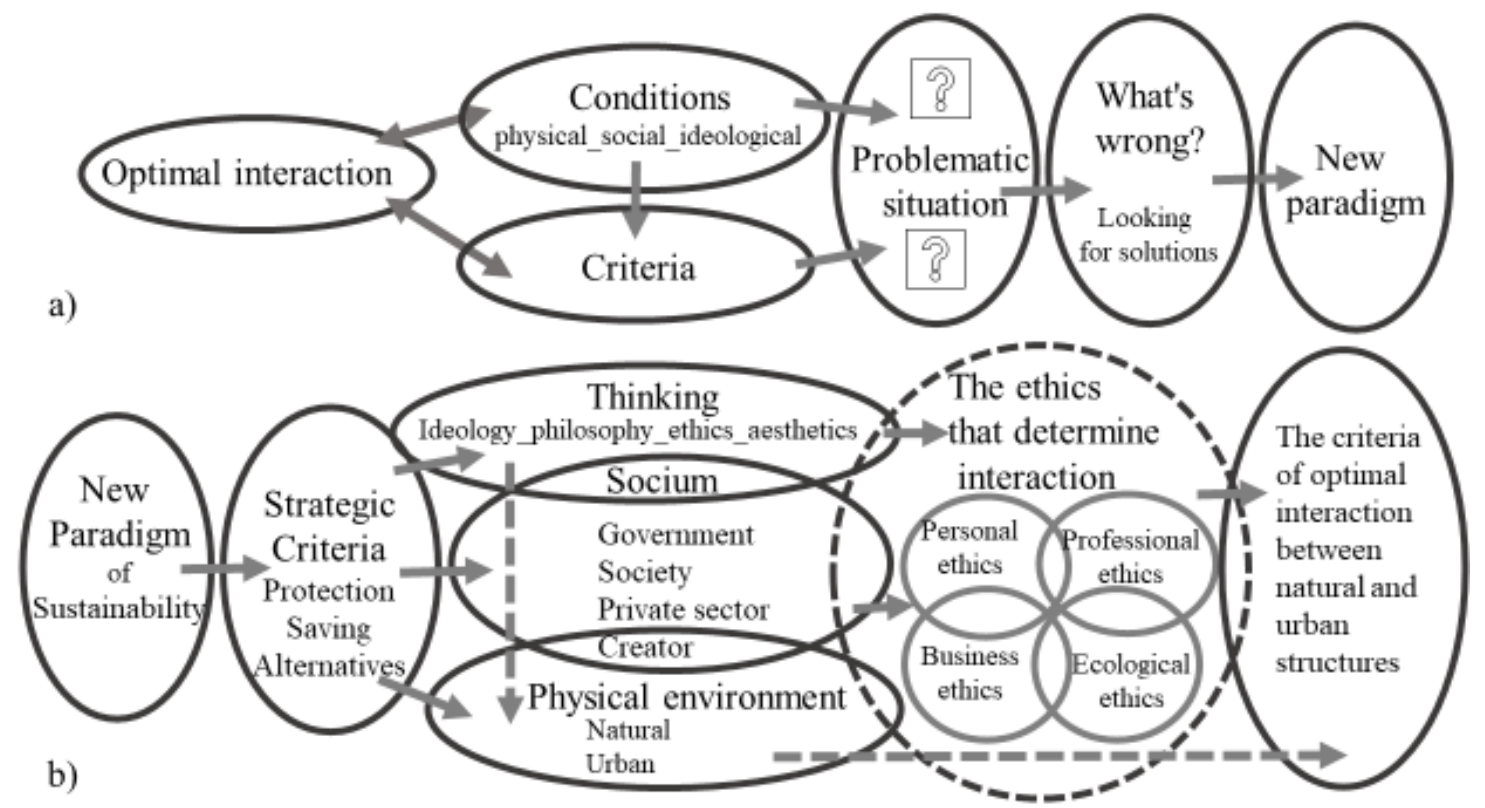

Fig. 1 a) Dependence of optimal interaction - principal diagram

b) formation of interaction optimization criteria - principal diagram

determine ecological and socio-functional values. The method aesthetical perception was chosen to determine the aesthetic values $[18 ; 26]$. The essence of this trine assessment is that each aspect of the assessment has the same number of criteria, since it is important to maintain the equivalence of all three aspects. The interaction of natural and urban structures is evaluated in separate clusters of criterions with scores from 1 to 5 . The aforementioned assessment of the interaction of natural and urban structures of the territory is mainly carried out using a subjective expert assessment method. It allows to obtain evaluations of three criterion clusters that show the strengths (highest scores) and the weaknesses (lowest scores) of the territory. However, whereas territories are highly different in terms of natural and urban morphology, and social needs, it is obvious that criteria should be prioritized inside the clusters. To this end, the Multi Criteria Decision Making (MCDM) method is used, by evaluating the importance of criteria in pairs based on their significance in a particular territory, and establishing the weights of the criteria. Criteria priorities are generally established using one of the MCDM methods, the so-called Analytic Hierarchy Process (AHP), which is popular and successfully used in planning, environmental protection, in addressing climate change problems and other issues where it is necessary to decide on the priorities of many criteria [25]. By applying the AHP method, the priorities of criteria are determined by pairing them according to their importance in a specific territory. The hierarchy of criteria is determined in separate clusters of ecological, social and aesthetic aspects [15]. The quantitative (numerical) expression of the assessment results is necessary for the comparison of individual values and illustration of the territory problems, revealed by evaluating in different aspects. At the stage of analysis and synthesis of evaluation results and preparation of conclusions, we come back to the qualitative analysis methods, using the methods of multilayer analysis, processuality, space sequencing and context characteristic, characteristic of landscape architecture $[19 ; 13]$. The experimental research is based on the orthophoto photo and other GIS data with photos, by using the spatial grids method.

\section{Basic principles for Methodological model}

The main subject of the research is the interaction of natural and urban structures, interpreting it from the landscape architecture point of view. The work of the French sociologist and philosopher Edgar Morin on significance, expression and peculiarities of interaction has seemed acceptable to the author for this work. In his philosophical works, he analyses of the research subjects by combining for features of interaction operating in a close dynamic synergy - confrontation, supplementing, competition, collaboration. Interaction is understood as a basis of any system, because it includes the exchange of information, emotions or energy between two actors in one system [21]. Interaction between natural and urban structures occurs in various aspects and can be physical, visual, and psychological. It involves natural and man-made processes and is examined through the prism of urba-ecological and social needs and services. The research focuses specifically on the provocative interaction developed by human actions, which determines further processes and interactions. There are usually three main groups of people involved in urban processes in one or another process of interaction. These are the customer 
The scale of landscape management levels according to the pyramid of human needs [20, compiled by the author]

\begin{tabular}{|c|c|}
\hline Human needs & Environment from the point of view of landscape architecture \\
\hline $\begin{array}{l}\text { REQUIREMENTS FOR SELF } \\
\text { REALIZATION: spírituality, development, } \\
\text { self-realization, raising personal goals and } \\
\text { their implementation }\end{array}$ & $\begin{array}{l}\text { Ensuring environmental spirituality: preservation and disclosure of } \\
\text { the local spirit; preserving and fostering cultural landscape; creation } \\
\text { of educational conditions; community self-expression opportunities; } \\
\text { artistic expressions, aesthetic experiences. }\end{array}$ \\
\hline $\begin{array}{l}\text { NEEDS FOR RESPECT: } \\
\text { self-esteem, independence, } \\
\text { success, attentílon, recognition, social status } \\
\vdots\end{array}$ & $\begin{array}{l}\text { Ensuring the quality of the environment: tidy, comfortable } \\
\text { environment; a variety of composite solutions that provide freedom of } \\
\text { choice; public participation and respect for its opinions; optimal and } \\
\text { cost-effective solutions; cost-effective and creative use of natural } \\
\text { resources. }\end{array}$ \\
\hline $\begin{array}{l}\text { SOCIAL N'XEDS: communication ; societies; } \\
\text { appearance; monitoring; cooperatiōn, } \\
\text { usefulness }\end{array}$ & $\begin{array}{l}\text { Assurance of socialization factors: adaptation of territories for } \\
\text { different age groups and various needs; integration of people with } \\
\text { disabilities; accessibility and availability of recreational territories; } \\
\text { ensuring of get-togethers and seclusion. }\end{array}$ \\
\hline $\begin{array}{l}\text { SECU'RITY AND WELFARE NEEDŞ: } \\
\text { physical, emotional and material security; } \\
\text { avoíding danger; health, child safety and, } \\
\text { education; sport; endurance training }\end{array}$ & $\begin{array}{l}\text { Assurance of safety factors: physical safety of the environment; } \\
\text { clean and healthy environment; health facilities; sufficient size of the } \\
\text { recreational area; protection of natural resources; public and private } \\
\text { interests. }\end{array}$ \\
\hline $\begin{array}{l}\text { P/HYSIOLOGICAL NEEDS: } \\
\text { air, food, physical comfort, sleep; hygiene; } \\
\text { mutrition; shelter, movement - - - } 1 \\
\end{array}$ & $\begin{array}{l}\text { Satisfaction of physiological needs: clean air flows; light/shadow; } \\
\text { sufficient moisture; noise protection; nutritional and expelling needs; } \\
\text { satisfaction of leisure and activity needs. }\end{array}$ \\
\hline
\end{tabular}

(may be private or public), the creator (designer) and the public (user). Any of these three actors may be the first to "move" the process towards a new interaction. Ideally, all three groups understand and evaluate the situation, in which the new interactions occur, in a similar manner; in such case one can expect optimal decisions to be made (Fig. 1a and b). "Optimization" in dictionaries is defined as "finding the best way to solve a problem or task according to a predefined criterion". In the research, optimal interaction is understood as the result of human activity in finding the best solution according to predetermined criteria. The optimal interaction is characterized by the preservation of semantics, rational use of resources and elimination of repetition of excessive functions.

Thus, the most important question arises at this point - on what values will we base the optimality criteria for ourselves? Landscape architecture is very close to the environmental or ecological ethics in which we discover the same values as memory (mémoire), heritage (patrimoine), landscape identity (l'identitè de paysage), biodiversity (biodiversité), solidarity (solidarité), freedom and peace (liberté et paix), well-being and better living (mieux-être et mieux-vivre) [8]. Ecological ethics also defines the principles of expediency and optimality: (1) protection of available natural and anthropogenic resources, safe and creative their use; (2) considering the context and creative adaptation; (3) synergy between social services (adequacy and complementarity of each other); (4) combining ecological, aesthetic and socio-functional issues into unified solutions. Sociologists studying consumption problems notice that consumption can be understood as unlimited desires and as necessary needs.
The first case is the problem of a modern society. An unlimited desire to waste natural resources often turns into desire to dominate on the nature and manage it. And although, according to the philosopher A. Maceina, the control over nature does not interrupt human relations with nature, but binds them even more, but if there is no longer moral moment in this relationship, it becomes harmful both to nature and to human [28].

To analyse the landscape and the living environment, we adapted Maslow's pyramid of human needs and motivation [20], in which, according to the scale of needs, we interpreted the landscape management levels (Table 1). In practice, in examining any territory, one can look at the level of human needs in which our environment is. It is important to understand the consistency of this scale - until the foundation for the basic needs is created, there is no sense in the efforts for a higher level. It is precisely the ecological ethics and landscape architecture values and methods that allow to achieve consistent growth of the territory quality.

The logic of optimality claims that before we make any decisions about the development of the territory, we first need to make sure how it is special, what we have to preserving it and how to complement it. This means that it is first necessary to evaluate the chosen territory, to identify its strengths and weaknesses and, in the light of the evaluation results, to propose the optimal variants for further management. In order to ensure optimal solutions, we have: (1) to know very well the strengths and weaknesses of the territory in question; (2) to examine context opportunities and systemic links; (3) to analyse the needs according to the opportunities and threats provided by the situation 


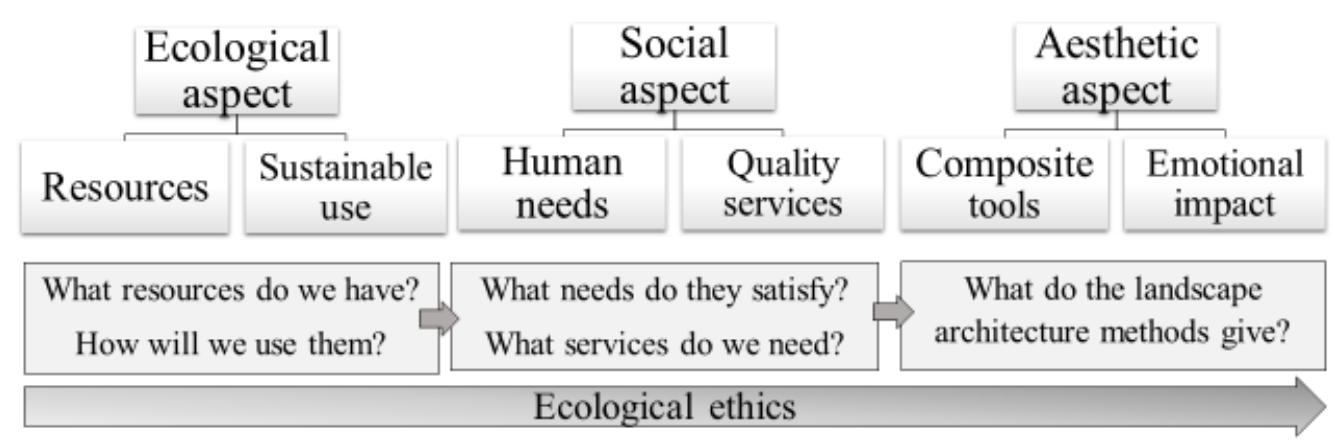

Fig. 2. Three-member system of assessment criteria based on the principles of sustainable ecological ethics [created by author]

and context; (4) to search for new solutions enriching the situation, through synergies; (5) to provide for possible natural and social processes in space and time, and to make sure that we do not create obstacles for them to go without interruption; (6) to set priorities for choosing the principles and tools for the territory management.

\section{Three-dimensional system of criteria}

The research has to answer the three main questions: (1) What resources do we have and how will we use them? (2) What needs are best met by the resources available and what services do we still lack? (3) What can landscape architecture principles and measures in assimilating and managing the territory offer? In accordance with the sustainability paradigm, ecological ethics and logic of optimality, a three-dimensional system of evaluation criteria, consisting of ecological, social and aesthetic criteria groups, is formed (Fig. 2). The three groups of criteria are drawn up in such a way that the results of the evaluation in one aspect provide information or raise the question to another aspect. For example, high results of ecological assessment can prompt socio-functional priorities and focus on specific compositional means for creating an aesthetic impact. The purpose of this assessment is to highlight the features of the territory - strengths and weaknesses, so that we can make decisions about how to strengthen the weak positions without weakening the strengths.

The main task and the guarantor of success of each assessment is the correct and universally chosen criteria. When evaluating from the ecological point of view, it is important for us to find out if there are natural structures in the territory that are treated as a very valuable and cherished property of the territory. Secondly, it is important to understand the level of biodiversity that surrounds us, so that we do not destroy it by irresponsible actions, but creatively integrate in our territory development plans. Thirdly, it is important to consider whether there are ecosystems created (or built up) in the territory that already have an independent life and are worthy of maintaining, nourishing or improving. Fourthly, it is necessary to clarify the capacity of both natural and created natural structures (in other words, green infrastructure) in relation to existing urban conditions. In this research, the following ecological aspect criteria recognised as important in scientific literature and other research, are used: naturalness (wildness), biodiversity, built ecosystems, and ecological carrying capacity.

Naturalness (wildness) is the most natural forms of natural preserved structures. For example, natural land surface areas, naturally growing trees, shrubs and herbaceous vegetation, naturally formed water bodies. The natural terrain in the research is understood as the earth's surface formed by natural processes, which is not substantially altered by anthropogenic processes. When assessing the naturalness of a water body, its nature is very important - stream, source, river, lake, sea, etc. Biodiversity - in this study, biodiversity of all types of vegetation is taken into consideration such as insects, birds, fish and other living creatures - they are predicted according to the principles of symbiosis - and their probability corresponds to the size of the habitat. The terrain is evaluated by how it is adapted to the disclosure of biodiversity. The biodiversity of the water body is assessed by the extent to which the surrounding vegetation creates opportunities for the expansion of the biodiversity. The score awarded is determined by the size of the territory with biodiversity in relation to the territory in question. Built ecosystems - green infrastructure based on innovative, sustainable engineering solutions. The terrain is evaluated depending on how it's management solutions take part in the storm water open management system; afforestation of roofs, terraces, decks; noise and air pollution abatement measures. In the assessment of water, consideration is given to whether open storm water management is provided for/implemented in the solutions; landscaped roofs as a means of storm water management; water ecosystem created; accumulated water - a watering tool. Also, the score is given to the territory where the water-conducting 
Criteria for aesthetic perception according to R. and S. Kaplan [18]

\begin{tabular}{|c|c|l|}
\hline Criterion & Understanding type & \multicolumn{1}{c|}{ Evaluation issue } \\
\hline Coherence & direct understanding & $\begin{array}{l}\text { Do the images fit together? Is the structure and } \\
\text { composition of the environment easy to perceive? }\end{array}$ \\
\hline Complexity & direct exploration & $\begin{array}{l}\text { Is it interesting to observe the environment? Is the } \\
\text { variety of images big? }\end{array}$ \\
\hline Legibility & inferred understanding & $\begin{array}{l}\text { Is it easy to imagine a further path when walking } \\
\text { forward and backward? Is it easy to orient in the } \\
\text { environment? }\end{array}$ \\
\hline Mystery & $\begin{array}{l}\text { How promising is the visible landscape if you go } \\
\text { further? Are images that are still invisible causing } \\
\text { curiosity? }\end{array}$ \\
\hline
\end{tabular}

coating ratio is $3 / 2$ to the hard surfaces. Ecological carrying capacity - assessing whether natural and developed natural structures act as a system, and whether they interconnect. The extent to which natural structures are stable, namely, how much they are resistant to pollution or other physical effects, is considered. The level of integrity and perforation of natural structures is assessed - the more coherent the structure is, the greater its ecological carrying capacity. The potential for regeneration (and renewal) of natural resources (land, air, water, wildlife, vegetation) is assessed. An important indicator is also the ratio of built up and natural areas in the territory.

In the social aspect, the aim is to find out what social functions the territory values imply, which services should be included in the development plans of the territory, in order to make the best use of the available natural and anthropogenic resources and without compromising, create the services that are maximally tailored to the situation. For the social aspect assessment, a series of criteria corresponding to the human needs scale is formulated accessibility, safety, social integration and participation, shared functions.

Accessibility is related to meeting the basic needs by ensuring basic physiological needs - pure air flow; the need for light and shadow; comfortable and sufficient moisture balance necessary for a person; noise protection, etc. When assessing the territory, it is important to make sure that there are at least minimum recreational conditions, whether paths are not closed and access to recreational resources is provided; whether the satisfaction of recreation and activity needs is guaranteed. It is assessed whether the movement trajectories are adapted to the terrain, or whether access to the highest points of sightseeing are ensured. It is also assessed whether access to the water body, movement along its coast, and visual contact are ensured. Accessibility is also assessed in terms of adaptation of territory for the disabled. The safety criterion relates primarily to the level of territory maintenance. It assesses both the physical and social safety of the environment and factors that can lead to security problems. Abandoned, disorderly territories with signs of antisocial activity are considered unsafe. Also unsafe are territories contaminated with chemicals, with polluted air and high noise territories. If there are abandoned buildings in the territory, it is also considered to be potentially unsafe. The safety parameters are reduced by blind facades and fences, hardly accessible nooks, pits, etc. The risk of the territory of becoming unsafe is greatly increased by heavy vehicle movement, limiting pedestrian flows and complicating safe movement. The social integration and participation criterion must first of all demonstrate whether the community is interested in its environment, or there are indications that people tend to take care of the environment altogether. The concept of social integration and participation suggests that public spaces must be adapted to different uses. When evaluating the territory, it is important to involve various stakeholders of the community, volunteering, co-farming, etc. When assessing the environment, we should consider whether there are conditions for self-expression of the community, the disclosure of local identity, the development of landmarks and points of attraction. The shared function criterion defines how closely they related functions fit together, to what extent they are adequate, and how much they can complement each other. It considers whether or not the services provided are synergic, do not duplicate or copy each other. One of the features of the function compatibility are integral engineering and composition solutions. Combined functions include building facades and entrances that are properly compatible in terms of the landscape architecture object, allowing the successful development of catering, cultural or recreational services in the territory of the park or other greenery.

The criteria for aesthetic aspect in scientific explorations and research are often considered together with the ecological social criteria, without distinguishing them into a separate group. Given the fact that a wide variety of composite tools are used in the formation of urban spaces and landscape which have a purpose of causing a variety of human 


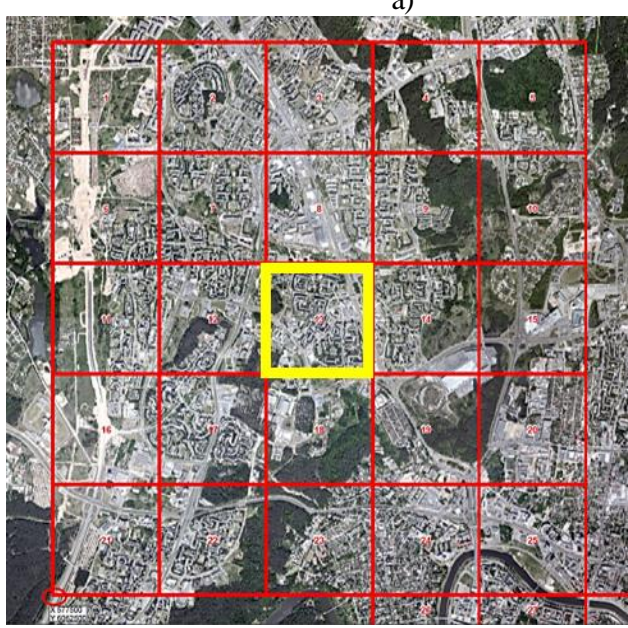

b)

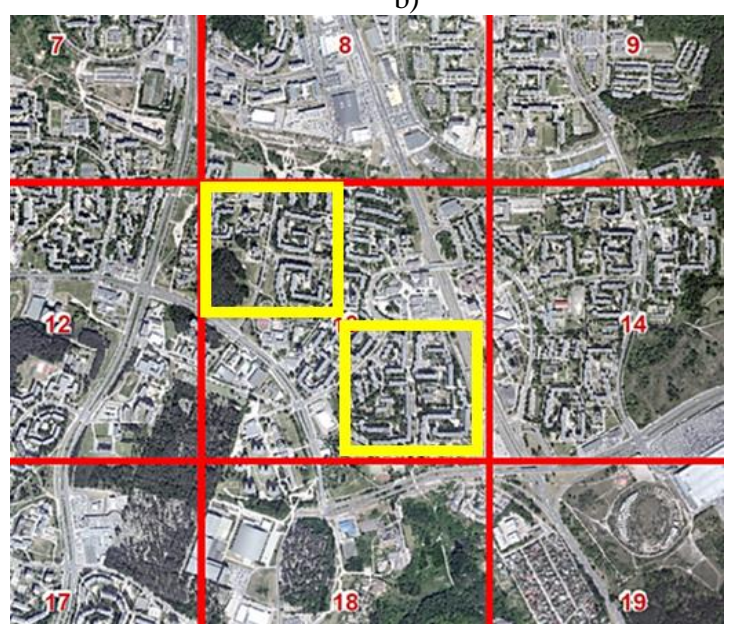

Fig. 3 a) Northern territory of the city of Vilnius as covered with 1 square. km spatial grid; b) example of division to sub-grids $(500 \mathrm{~m} \times 500 \mathrm{~m})$ [created by author]

reactions or emotions, we chose to evaluate the interaction of natural and urban structures using the aesthetic impact criteria. One of the most widely known environmental psychology theories was developed by the scientists Rachel and Stephen Kaplan [18; 26] research model - mystery, complexity, legibility, coherence. This theory relies on two basic human needs for the environment - to understand it and to explore it. In accordance with this principle, four main criteria for environmental emotional feeling or aesthetic feeling were distinguished. They are grouped by scientists into the groups of immediate understanding and immediate exploration, and inferred understanding and inferred exploration (Table 2).

\section{The experimental research}

For the research, the quarters located in the northern part of Vilnius, with main urban framework formed in around 1980-1990, but quite well developed at the present time, were chosen. The research area includes Pašilaičiai, Fabijoniškès, Šeškine, Viršuliškès and other densely populated districts. The research focuses on the issues at the quarter level. The research analysed the interaction between the natural and urban structures of the territory, treating the latter as an important field of creative activity of the landscape architecture. In order to cover as many potential scenarios as possible in the expression of landscape architecture, we chose to explore not specific objects, but to examine the continuous problematic urban territory, covering it uniformly in a spacious grid.

The territory is uniformly covered with $1 \mathrm{sq}$. km grids, which corresponds to the division of the quarter level (Fig. 3 a). The method of this size of a standard grid is applied in European landscape monitoring systems and specialists recommend the transition to a unified landscape monitoring system in Lithuania [33]. There are 25 grids in total to analyse, covering a total territory of 25 square meters $\mathrm{km}$. The analysis of $1 \mathrm{sq}$. $\mathrm{km}$ of the grids showed that quite different forms of interactions between urban and natural structures can be found in such size of grid. It was decided that territorial units of research should be broken down to a smaller unit - sub-grids of $500 \mathrm{~m} \mathrm{x} 500 \mathrm{~m}$, where the characteristic features of the physical interaction of urban and natural elements appear to be the best (Fig. 3 b).

A total of 100 surveyed territorial units were developed for the research. Their primary analysis showed that features of interaction between natural and urban structures in separate grids have commonalities that can be grouped together, in order to distinguish certain types of physical interactions. In the current stage of a specific research, no detailed morphological analysis of urban landscape is performed, but in principle, distribution according to the characteristic features of physical interaction of natural and urban structures close to it allows development and interpretation of results also from the morphological viewpoint in subsequent stages of research. Fig. 4 shows the distribution of sub-grids of the northern territory of the city of Vilnius $(500 \mathrm{~m} \times 500 \mathrm{~m})$ according to the predominant features of physical interaction.

Relevant research in assessing the peculiarities of interactions between natural and urban structures was carried out in different grids (500 m x $500 \mathrm{~m})$. For the objectivity purposes, the grid was chosen randomly for the research, according to the "biopsy" principle, as this random arrangement of the monitoring benchmarks in most scientific works is recognized as the most appropriate [33]. We present an example of grid 13.4 (Fig. 5). The territory in question is located in Šeškinè district, built in about 1980. It is dominated by preplanning apartment buildings of 5 to 9 storeys of reinforced concrete blocks featuring long facades, arranging the 


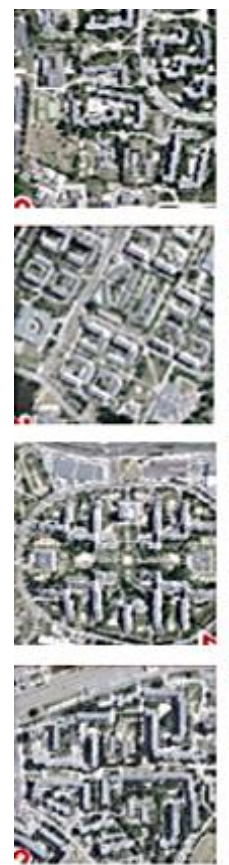

A
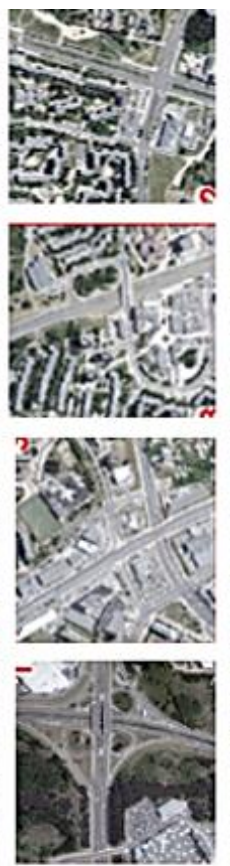

$\mathrm{B}$
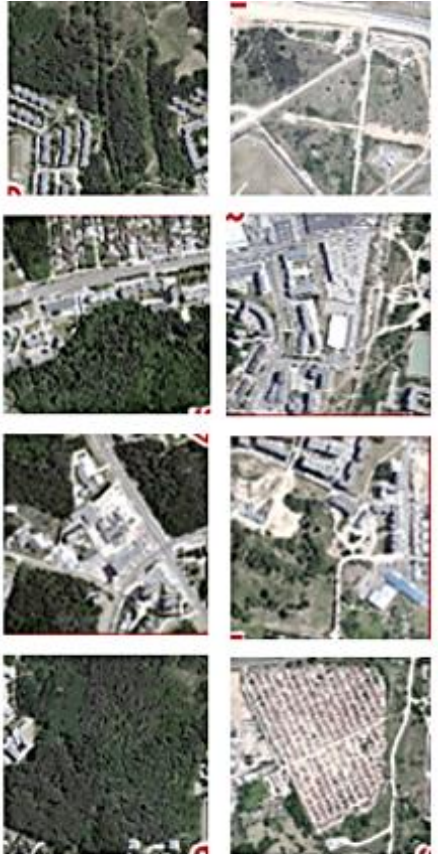

$\mathrm{C}$

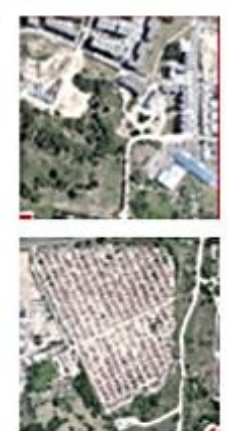

$\mathrm{D}$
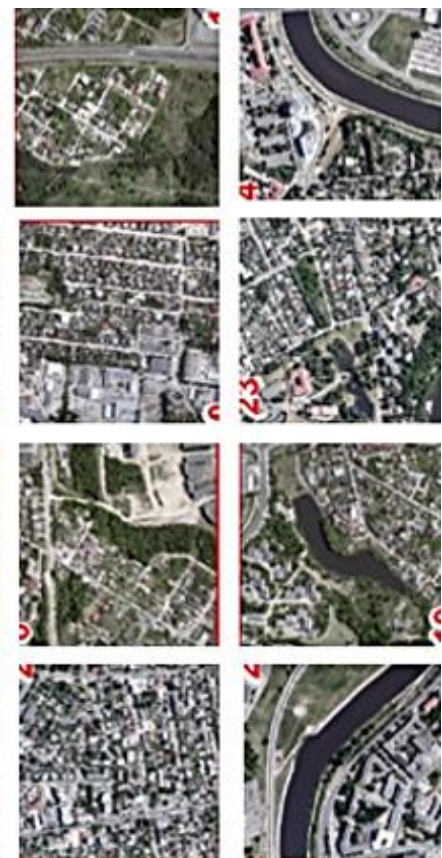

$\mathrm{E}$
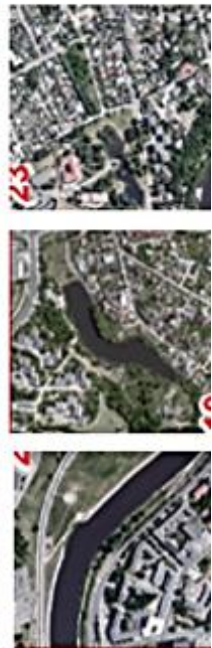

$\mathrm{F}$

Fig. 4. Breakdown by the dominant features of physical interaction of natural and urban structures in separate grids: $\mathrm{A}$ - dominated by open spaces of apartment buildings; $\mathrm{B}$ - dominated by transport infrastructure; $\mathrm{C}$ - dominated by forest areas; $\mathrm{D}$ - urban deserts; $\mathrm{E}$ - dominated by homestead buildings; $\mathrm{F}$ - dominated by water bodies [created by the author]
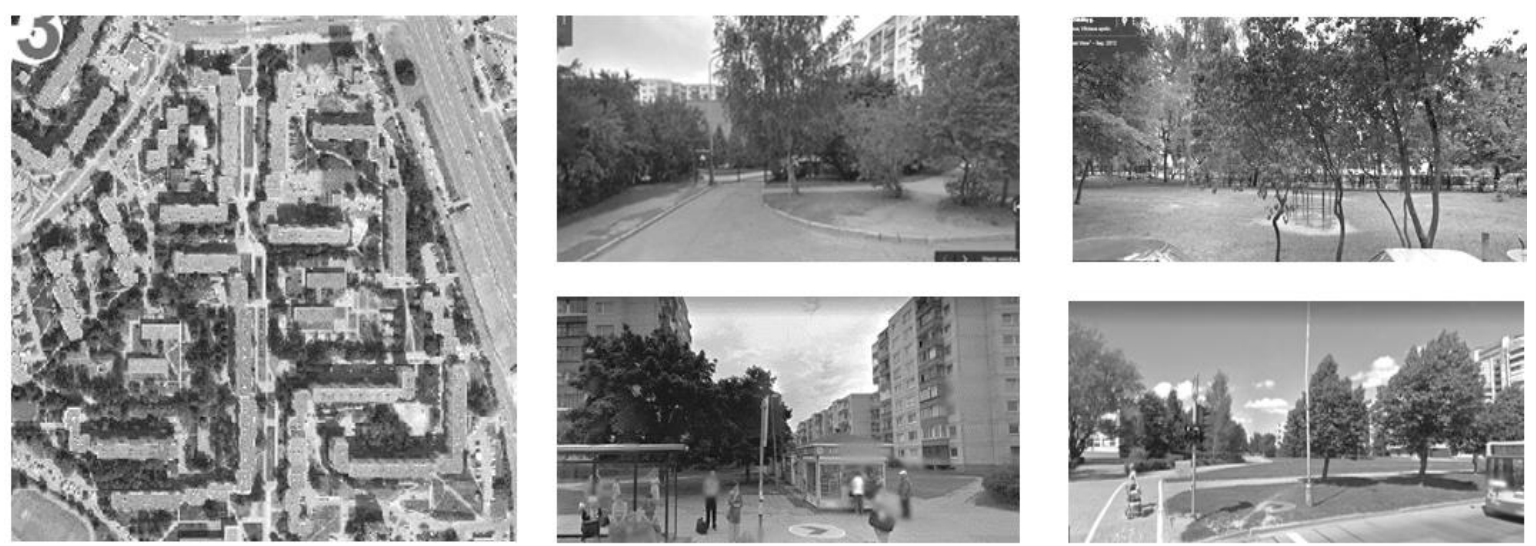

Fig. 5. The spatial grid (13.4) of $500 \mathrm{~m} \times 500 \mathrm{~m}$ was used for the research [created by the author]

TABLE 3

Example of expert assessment of interaction between natural and urban structures (ecological criteria cluster) [created by the author]

\begin{tabular}{|c|c|c|c|c|c|c|c|c|c|c|c|c|c|c|c|c|c|c|c|c|c|}
\hline \multirow[b]{2}{*}{13.4} & \multicolumn{4}{|c|}{ Paths } & \multicolumn{4}{|c|}{ Edges } & \multicolumn{4}{|c|}{ Nodes } & \multicolumn{4}{|c|}{ Landmarks } & \multicolumn{4}{|c|}{ Districts } & \multirow[b]{2}{*}{$\stackrel{\overparen{\Xi}}{0}$} \\
\hline & 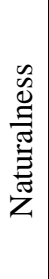 & 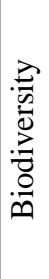 & 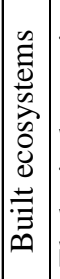 & 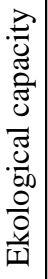 & 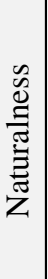 & 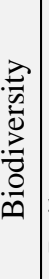 & 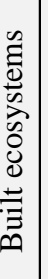 & 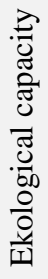 & 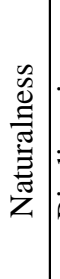 & 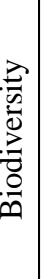 & 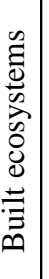 & 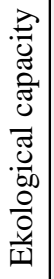 & 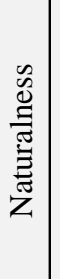 & 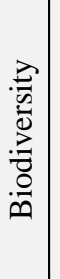 & 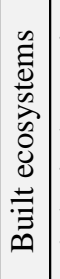 & 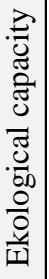 & 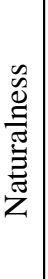 & 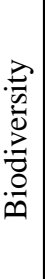 & 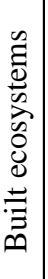 & 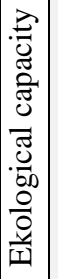 & \\
\hline Soil & 2 & 2 & 1 & 1 & 3 & 3 & 2 & 1 & 2 & 2 & 1 & 1 & 2 & 2 & 1 & 1 & 2 & 2 & 1 & 1 & 33 \\
\hline Water & 0 & 0 & 0 & 0 & 0 & 0 & 0 & 0 & 0 & 0 & 0 & 0 & 0 & 0 & 0 & 0 & 0 & 0 & 1 & 0 & 1 \\
\hline Plants & 3 & 3 & 2 & 1 & 3 & 3 & 3 & 2 & 3 & 2 & 2 & 1 & 2 & 2 & 1 & 1 & 3 & 3 & 2 & 1 & 43 \\
\hline \multirow{2}{*}{ Total } & 5 & 5 & 3 & 2 & 6 & 6 & 5 & 3 & 5 & 4 & 3 & 2 & 4 & 4 & 2 & 2 & 5 & 5 & 4 & 2 & \multirow{2}{*}{77} \\
\hline & \multicolumn{4}{|c|}{15} & \multicolumn{4}{|c|}{20} & \multicolumn{4}{|c|}{14} & \multicolumn{4}{|c|}{12} & \multicolumn{4}{|c|}{15} & \\
\hline
\end{tabular}


buildings in the shape of the letter $\mathrm{L}$ and creating semi-enclosed courtyard spaces. The spatial grid in question has two pre-school institutions with sufficiently spacious enclosed territories. The buildings are mirror-situated on both sides of the pedestrian walkway in the north-south direction. The terrain is less expressive and has a common north-south slope. According to the dominant features of physical interactions of natural and urban structures, the grid in question is classified as the type "Internal open spaces of apartment buildings".

The interaction of natural and urban structures is evaluated in separate clusters of the three-criterion system, by signing points from 1 to 5 , where 1 point is very weakly expressed; 2 - weakly expressed; 3 - average; 4 - strongly expressed; 5 - very strongly expressed interaction. If some element of the natural structure is missing - we write zero (Table 3).

\section{Results and Discussion}

By adapting the method of subjective expert assessment, the assessments of the interaction between the natural and urban structures of the territory obtained are quite similar to each other $-77,74,76$ points, respectively. This shows that the territory does not have highly unique interaction properties, and the level of interaction is rather low - the score obtained for each of the positions is below $30 \%$ of the possible score (the maximum possible amount is 300 points). The summarized results of the interaction of the natural and urban structures of the territory under consideration are presented in Table 4.

The strengths and weaknesses of the territory are determined during the analysis of evaluation results - they are distinguished by comparing data with each other. For example, in all three groups of criteria, plants (40-43 points) are in more active interaction with urban structures than terrains (30-34 points). Both the plant and the terrain expression is the strongest in the boundaries, in terms of ecological and aesthetic aspects. The least interaction of natural and urban elements is expressed in the formation of landmarks. The results of the interaction evaluation are analyzed in more detail in the criteria groups or clusters, where a maximum score of 75 is possible for each of the sub-criteria. The results of evaluation of grid 13.4 in question are presented in Fig. 6, reflecting the evaluation scores obtained and their relationship with the possible maximum score. The highest scores were given to "naturalness" (25) for ecological aspect and "cohesion" (25) for assessing from the aesthetic aspect. Accordingly, the second place are assessments by the sub-criteria "biodiversity" and "legibility", each scoring 24 points. The "ecological carrying capacity" (11) and
TABLE 4

Summarised results of evaluation of the interaction of natural and urban structures in grid 13.4. [created by the author]

\begin{tabular}{|c|c|c|c|c|c|c|c|c|c|c|c|c|c|}
\hline $\begin{array}{c}\text { Cluster of } \\
\text { criteria }\end{array}$ & & & & & & & & & & $\Delta$ sot & & & \\
\hline $\begin{array}{l}\text { Obje } \\
\text { intera }\end{array}$ & 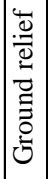 & 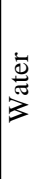 & 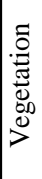 & 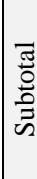 & 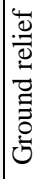 & $\begin{array}{l}\dot{\bar{d}} \\
\bar{\omega} \\
z\end{array}$ & 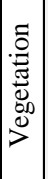 & 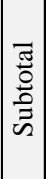 & 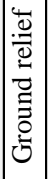 & 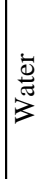 & 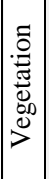 & 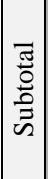 & $\frac{\pi}{6}$ \\
\hline the & 6 & 0 & 9 & 15 & 8 & 0 & 8 & 16 & 6 & 0 & 9 & 15 & 4 \\
\hline Edges & 9 & 0 & 11 & 20 & 7 & 0 & 9 & 16 & 9 & 0 & 11 & 20 & 5 \\
\hline Nodes & 6 & 0 & 8 & 14 & 7 & 0 & 8 & 15 & 6 & 0 & 8 & 14 & 43 \\
\hline Landn & 6 & 0 & 6 & 12 & 6 & 0 & 6 & 12 & 6 & 0 & 6 & 12 & 36 \\
\hline Districts & 6 & 1 & 9 & 16 & 6 & 0 & 9 & 15 & 6 & 0 & 9 & 15 & 46 \\
\hline Total & 33 & 1 & 43 & 77 & 34 & 0 & 40 & 74 & 33 & 0 & 43 & 76 & 22 \\
\hline
\end{tabular}

the "mystery" of the territorial got the lowest score (11). Evaluations between the sub-criteria of the social aspect cluster are distributed more evenly, by signing a slightly higher score, with the highest score by sub-criteria "inclusion" and "accessibility" (Fig. 6).

The interpretation of the evaluation results carried out by the subjective expert research method, based on the three-dimensional criteria system, highlights the features of natural and urban structures taking place in the territory - relatively stronger and weaker sides of this interaction (Table 5). Relatively higher score of natural biodiversity is attributable to the fact that the plantations growing in the territory are mainly native species, thus contributing to the formation of the natural environment, as well as to a certain level of biodiversity, which is somewhat random, and establishing due to modest mechanical and chemical maintenance of plantations, thus involuntary creating conditions for the development of natural communities, albeit small. Both ecologically and socially, the plantations are best revealed in the interaction with boundaries - mostly in the yards of apartment buildings, along the paths and the fences of preschool education institutions. They are also pronounced in the paths, which explains the relatively distinct "accessibility" score, which is given by assessing the population's ability to easily access natural structures and use their services. Aesthetically, the most significant interaction is within the boundaries of plantations, especially in terms of the criterion of coherence, because in uniformly planned urban spaces the relation between plantations, terrains and buildings is clearly perceived at the pedestrian paths. According to the research results, one of the weaknesses of the territory is that it does not contain any natural or artificial water body. The ecological carrying capacity of the territory is weak because natural structures are "overloaded and interrupted" by the 

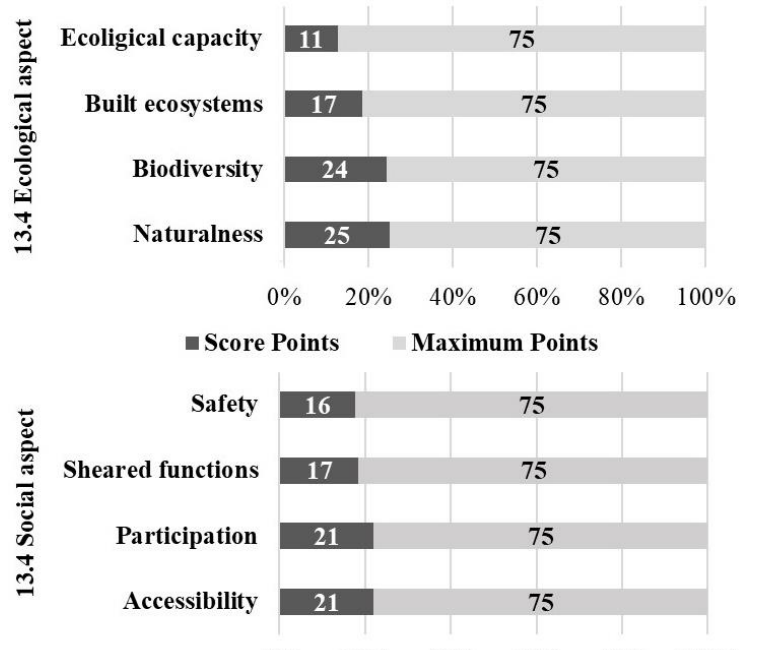

$\begin{array}{llllll}0 \% & 20 \% & 40 \% & 60 \% & 80 \% & 100 \%\end{array}$

- Score Points Maximum Points

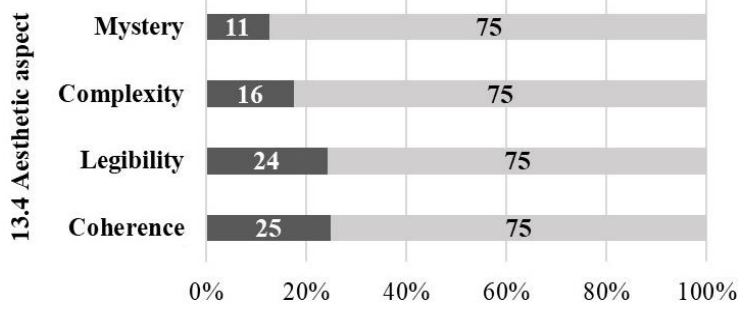

- Score Points Maximum Points

Fig. 6. Relative values of interaction between natural and urban structures (grid 13.4) [created by the author]

buildings and hard pavements. Natural structures, especially herbaceous plants, are unable to recover due to their constant mechanical damage and loads. There are few ecosystems in the territory that would interconnect and strengthen the green infrastructure of the quarter. The territory is considered unsafe because of chaotic parking of cars, worn out walkways and recreational areas, randomly formed nooks are to be seen as the attributes of the unsafe environment. The analyzed environment is formed by poor compositional means, therefore, there is no abundance and mystery in terms of emotional effect, the environment is not intriguing, it is not interesting to observe it.

During the analysis of the method of subjective expert assessment, the question of "how strongly the interaction between natural and urban structures in a given territory is expressed in terms of a unified system of criteria?" was investigated, and the results of evaluation show the relative distribution of values between the sub-criteria in the individual clusters of three-member criteria system. Regardless that the evaluation results are interpreted by highlighting the strengths and weaknesses of the interaction between natural and urban structures, the problem of objectivised prioritisation remains; it is solved by using the method of multi-criteria analysis and raising the question "which sub-criterion of the separate cluster of criteria is more important in a specific territory?". We present an example of how, by applying the analytical hierarchy process (AHP) method, the priorities of criteria are determined by evaluating them in pairs according to their significance in a particular grid 13.4. The significance of the criterion in respect of each other for evaluating the scores from 1 to 9 . The calculation was performed using the AHP-OS free internet access priority spreadsheet (https://bpmsg.com/academic/ahp.php). The prioritization process is illustrated in Table 6 .

By applying the multi-criteria analysis method, the priority ranking of sub-criteria in separate criterion clusters is determined (Table 7). In the cluster of ecological criteria, the importance of ecological carrying capacity and the created ecosystems comes first, with three positions remaining important socially - accessibility, safety and integration, respectively. From the aesthetic point of view, priority is given to the coherence and legibility sub-criteria.

Comparing the results of the assessment of the current situation in scores, and the preferred priorities (Table 8) set by the multi-criteria analysis, specific problem issues of clusters of interaction between natural and urban structures you might in specific clusters of criteria. From the ecological point of view, the strength of the territory in question - naturalness by priorities scale - is least significant, and the weakness - ecological carrying capacity - is one of the most important preferred priorities. In the cluster of social criteria, the strength is accessibility, and this criterion remains crucial in prioritising. The second priority is the safety priority, however, assessment according to it has received the lowest score in assessing the current situation. In the cluster of aesthetic criteria, the priority criteria included coherence and legibility, according to which, during the evaluation of the expert situation, the interaction between natural and urban structures was evaluated with relatively high scores. In search of the solution methods for optimum interaction between natural and urban structures, it is necessary to consider the features and priorities determined during the assessment of the territory. It means that we must establish the optimum priority criteria based on the ratio between valuable weak properties and preferred priorities. The score awarded during the expert assessment by criteria (RS) is multiplied by the percentage value of the preferred priority and a new relative numeric value is obtained, which represents the real importance of the priority criterion, in the light of the available valuable resources of the territory and their shortage inside of the cluster of criteria.

The list of reasonable criteria based on the analysis of the current situation is the main form of 
Prioritization process using the AHP-OS free internet access spreadsheet:

a) ecological aspect; b) social aspect; c) aesthetic aspect [created by the author]

a)

\begin{tabular}{|c|c|c|c|c|}
\hline $\begin{array}{c}\text { Subriteria of } \\
\text { ecological cluster } \\
13.4\end{array}$ & 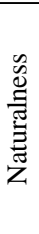 & $\begin{array}{l}\stackrel{\gtrsim}{0} \\
\frac{0}{0} \\
\stackrel{0}{0} \\
\stackrel{0}{0}\end{array}$ & 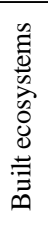 & 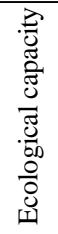 \\
\hline Naturalness & 1 & 0.5 & 0,2 & 0.11 \\
\hline Biodiversity & 2 & 1 & 0.5 & 0.5 \\
\hline Built ecosystems & 5 & 2 & 1 & 1 \\
\hline Ecological capacity & 9 & 2 & 1 & 1 \\
\hline
\end{tabular}

b)

\begin{tabular}{|c|c|c|c|c|}
\hline $\begin{array}{c}\text { Subriteria of } \\
\text { social cluster } \\
13.4\end{array}$ & 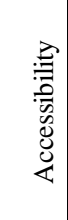 & 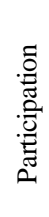 & 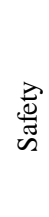 & 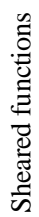 \\
\hline Accessibility & 1 & 2 & 1 & 7 \\
\hline Participation & 0.5 & 1 & 1 & 3 \\
\hline Safety & 1 & 1 & 1 & 6 \\
\hline Sheared functions & 0.14 & 0.3 & 0.2 & 1 \\
\hline
\end{tabular}

c)

\begin{tabular}{|c|c|c|c|c|}
\hline $\begin{array}{c}\text { Subriteria of } \\
\text { aesthetic cluster } \\
13.4\end{array}$ & $\frac{8}{0}$ & 离 & 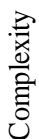 & 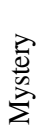 \\
\hline Coherence & 1 & 1 & 8 & 4 \\
\hline Legibility & 1 & 1 & 5 & 5 \\
\hline Complexity & 0.12 & 0.2 & 1 & 1 \\
\hline Mystery & 0.25 & 0.2 & 1 & 1 \\
\hline
\end{tabular}

Priority ranking of sub-criteria in separate criterion clusters [created by the author]

TABLE 7

\begin{tabular}{|c|c|c|c|c|c|c|c|c|}
\hline Ecological aspect & Priority & Rank & Social aspect & Priority & Rank & Aesthetic aspect & Priority & Rank \\
\hline 1. Naturalness & $6.50 \%$ & 4 & 1. Accessibility & $39.10 \%$ & 1 & 1. Coherence & $43.70 \%$ & 1 \\
\hline 2. Biodiversity & $16.80 \%$ & 3 & 2. Participation & $22.80 \%$ & 3 & 2. Legibility & $40.40 \%$ & 2 \\
\hline 3. Built ecosystems & $35.10 \%$ & 2 & 3. Safety & $32.00 \%$ & 2 & 3. Complexity & $7.30 \%$ & 4 \\
\hline 4. Ecological capacity & $41.60 \%$ & 1 & 4. Sheared functions & $6.00 \%$ & 4 & 4. Mystery & $8.60 \%$ & 3 \\
\hline
\end{tabular}

TABLE 8

Analysis of the relation of values and priority criteria for expert scoring of the territory.

$\mathrm{RS}$ - awarded rating score; $\mathrm{PC}$ - priority criteria; $\mathrm{OP}$ - optimal priority [created by the author]

\begin{tabular}{|c|c|c|c|c|c|c|c|c|c|c|c|}
\hline \multicolumn{4}{|c|}{ Cluster I } & \multicolumn{4}{c|}{ Cluster II } & \multicolumn{3}{c|}{ Cluster III } \\
\hline $\begin{array}{c}\text { Ecological } \\
\text { criteria }\end{array}$ & RS & PC & OP & $\begin{array}{c}\text { Social } \\
\text { criteria }\end{array}$ & RS & PC & OP & $\begin{array}{c}\text { Aesthetic } \\
\text { criteria }\end{array}$ & RS & PC & OP \\
\hline Naturalness & 25 & 0,065 & 1,63 & Accessibility & 21 & 0,391 & 8,21 & Coherence & 25 & 0,437 & 10,93 \\
\hline Biodiversity & 24 & 0,168 & 4,02 & Participation & 21 & 0,228 & 4,79 & Legibility & 24 & 0,407 & 9,7 \\
\hline $\begin{array}{c}\text { Built } \\
\text { ecosystems }\end{array}$ & 17 & 0,351 & 5,97 & Safety & 16 & 0,328 & 5,12 & Complexity & 16 & 0,073 & 1,17 \\
\hline $\begin{array}{c}\text { Ecological } \\
\text { capacity }\end{array}$ & 11 & 0,416 & 4,58 & $\begin{array}{c}\text { Sheared } \\
\text { functions }\end{array}$ & 17 & 0,06 & 1,2 & Mystery & 11 & 0,086 & 0,95 \\
\hline
\end{tabular}

the tasks in the territory's management. For example, in order to optimize the interaction between natural and urban structures in the territory of grid 13.4 , it is essential to create new ecosystems and ensure the ecological capacity of the territory and promote its biodiversity. In social terms, it is most important to ensure the accessibility and safety, as well as to seek higher participation of the public. From the aesthetic point of view, the consistency of the composition and readability are most important.

The approaches of anamnesis (multilayer analysis), process, space sequencing, and context are used in landscape architecture making it possible to address all the priority tasks simultaneously, by combining solutions into a single whole [19; 13]. Anamnesis is the accumulation and analysis of information from different timelines, approaching to the present state of the landscape, when historical factors are integrated into the existing landscape from the natural to the artificial nature, including the spiritual and symbolic levels of society. All types of landscapes are seen as different layers of palimpsest - natural, cultural, infrastructural or developed with buildings. The process method creates the dynamics of natural and induced landscape changes. The process of site development in some direction is determined by the effect of nature and time as well as the design strategy. The creative process involves observation, protection and management of social and ecological systems. The landscape architect is structuring the potential landscape, knowing perfectly that his work will never be completed as a building. Spatial sequencing, or in other words, determining the sequence of spaces when one space complements the other, prepares for new impressions in the other space. Spatial consistency is a very important landscape design method. Spatial properties of the landscape are very dynamic and are fundamentally different from the static spatial properties characteristic to the building architecture. 
The role of participants in the interaction process in the principles of landscape architecture in implementing the priority tasks. The four main methods of landscape architecture are marked with A - anamnesis; P - process; $\mathrm{S}$ - spatial sequencing; C - context [created by the author]

\begin{tabular}{c|c|c|c|c|c|c}
\hline \multirow{2}{*}{ Priority criteria } & \multirow{2}{*}{$\begin{array}{c}\text { Optimal } \\
\text { priority } \\
\end{array}$} & \multicolumn{5}{|c}{ The actors of interaction } \\
\cline { 3 - 7 } & score & $\begin{array}{c}\text { Privat } \\
\text { person }\end{array}$ & Society & Authority & Business & Professionals \\
\hline Coherence & 10.93 & S & ASC & APC & SC & APSC \\
\hline Legibility & 9.3 & S & ASC & ASC & SC & APSC \\
\hline Accessibility & 8.21 & P & PC & APC & PSC & APSC \\
\hline Built ecosystems & 5.97 & PS & PC & APC & APC & APSC \\
\hline Safety & 5.12 & PS & PSC & PS & PSC & APSC \\
\hline Participation & 4.79 & P & PSC & PC & PC & APSC \\
\hline Ecological capacity & 4.58 & P & PC & APC & PC & APSC \\
\hline Biodiversity & 4.02 & P & P & AP & P & APSC \\
\hline
\end{tabular}

Areas such as topography (terrain), movement and horizon, and imagery relate to spatial sequencing. Context is an important and exclusive method of landscape architecture. The landscape design creates a context, and not only responds to it. Context creation consists of intensive relations of the function, image and space and their versatile combinations, by combining individual elements into a single composition. Landscape architecture is characterized by the feature to create a program from the landscape shape and context. The context principle obliges to look further beyond the boundaries defined for a project or analysis

The solution of priority tasks also requires a complex approach and a synergistic link between the interaction of the participants of the optimisation process of various natural and urbanist structures which, based on the nature of the operation, can be divided into five groups: private individuals, society/community, various levels of government, business enterprises and their representatives, and professional designers. Their joint action is conditioned by a unified approach to human relations with nature, evaluating their actions from the point of view of good and evil and formulating their behavioural principles in accordance with these categories [17]. As noted by I. Thompson, analysing ecological, aesthetic, social issues in landscape architecture, environmental management solutions are closely related to the use of land and its ownership, with the privileged lifestyle and willingness or unwillingness to change it [29]. Environmental or eco-ethics can help to find a common language in defining the key principles for the landscaping management. The ethical whole defining the interaction of natural and urban structures is formed by the ethics of each of the process participants - personal ethics, business ethics, professional ethics and ecological ethics. Each participant of the process influences whether the principles and methods of landscape architecture will be used timely and fully utilized to solve the real route challenges of the territory. The participation of the participants in the process of interaction between natural and urban structures in the implementation of the priority tasks, using the four main methods of landscape architecture, is presented in Table 9.

The results of the research show that in assessing the territory in all aspects, it is necessary to consider not only a specific plot or a defined area, but also to analyse the situation in adjacent territories, noting the areas not smaller than the area under consideration (Fig. 7). For example, in our research, we selected a conditional $500 \mathrm{~m} \times 500 \mathrm{~m}$ grid; in order to achieve the accuracy of the evaluation of this grid, it is necessary to examine the same size of the surrounding grids, in the specific case $-1500 \mathrm{~m} \mathrm{x}$ $1500 \mathrm{~m}$. Adequate expansion of the field of analysis is useful because both natural and social processes are not limited to legal or conditional boundaries. For example, there are no natural structures (forest, water, etc.) in the territory in question, but they are in the adjacent territory (or grid). Thus, by creating the ecosystems of our territory, we can (or perhaps we must) join to the existing large ecosystems. In social terms, we might ensure the connection of inhabitants of our territory with the common plantation system, and from the aesthetic point of view, the images of adjacent territories could be integrated into the landscape created by it. Fig. 7 shows the aggregated data of the grid 13.4 and its adjacent grids, which reflect the rating scores awarded (AS) during the assessment and the relative values (RV) obtained by comparing awarded rating score to the maximum score.

According to James Corner, based on the landscape architecture methods, in the managed area processes over time, mutual natural and social processes are created; all surfaces are creatively 


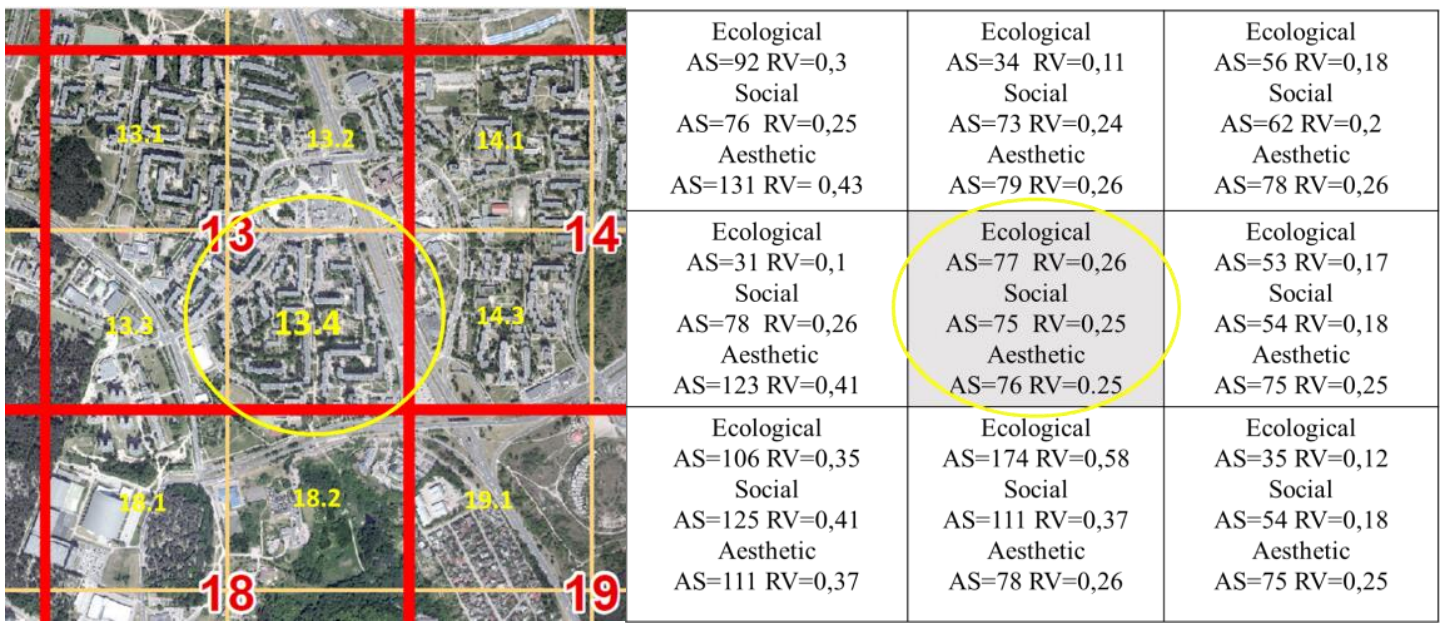

Fig. 7. Data of grid 13.4 in question and its adjacencies [created by the author]

arranged and staged; operational or working methods are offered for the participants of the interaction process; the imaginary emotionally attractive environment is created [5]. The study interprets the Jill Desimini's landscape management categories -community open spaces; ecological landscapes; blue-green infrastructure; workingproductive landscapes; transitional landscapes [7]. These categories are classified into separate grids according to their optimal priority needs, giving the territory a general direction in landscape management.

\section{Conclusions}

Natural and urban structures form the integral fabric of the city, and their interaction depends on the ethical attitudes of the urban process participants - the private person, the public, authorities, business enterprises and professional designers, their mutual understanding and collaboration. In the context of the challenges of today's world, the optimal interaction of natural and urban structures is conditioned by the concept of a sustainable city, which is achieved through ecological ethics.

Landscape architecture is an exclusive discipline that generates designer competencies that allow them to take on the tasks of rational and creative integration of natural and urban processes, both in the stages of city strategy development, and planning and design stages. Using the methods and principles of landscape architecture in urban management, one can expect optimal results of interaction between natural and urban structures.

The paradigm of sustainable urban development encourages the use of natural and anthropogenic resources in a cost-effective and reasonable manner, therefore, before engaging in the tasks of urban territory management, it is necessary to have a comprehensive knowledge about the properties of the territory in question and its context.
By using a three-member territorial assessment system consisting of three separate clusters of ecological, social and aesthetic criteria, the sitespecific values and problem properties are determined - the strong and weak characteristics of the existing condition.

By applying the multi-criteria analysis method, the priorities of the preferred criteria are identified and compared with the results of the assessment of the current state of the territory. The ratio of the assessment score of the territory according to the criteria with the weight of the preferred criterion identified by the analytical hierarchy process method indicates the optimal value of the priority criterion, based on the compatibility of the existing natural and urban characteristics of the territory and the established priorities. This determines the optimal sequence of the priority criteria.

By applying the four main approaches to landscape architecture, a new approach to urban management and development priorities is created. Natural and urban structures are consistently interconnected to systems that generate synergistic processes involving all participants in the interaction process. New ecosystems are integrated into the existing ecological system, preserving the key links and strengthening the ecological capacity of the territory. The same ecosystems serve the social needs of people - ensuring the accessibility and security of green areas, creating spaces for self-expression of the public. The coherent composition of spaces and the integration of context creates a sense of harmony and strengthens the readability and perception of the territory, and enhance the local identity.

The method of spatial grid implies a contextual approach to the territory under consideration. Splitting the territory into defined territorial units highlights the characteristic features of physical and social interaction of natural and urban structures. 
The specificity characteristic to the grid is compared to the characteristics of the adjacent grids, looking for the necessary ecological, social and aesthetic interfaces. The grid's method reflects the principle of design - from the whole to the detail, from the detail to the whole. This method encourages the territory to be examined through the landscape prism, going beyond the boundaries of the parcel.
It is recommended to associate the problem of interaction between natural and urban structures and solutions of the territory management with neighbourhoods located around in the grids of the same size.

\section{References}

1. Abaut-de Chastene, C., Contribution pour la caractérisation d'un " paysage urbain durable » dans les opérations d'aménagement Paris. Doctoral thesis, 2011.

2. Bchir Jaber, N., Le paysage urbain, généalogie et pratiques actuelles. Doctoral thesis, 2013.

3. Berleant, A., Sensibility and sense: The Aesthetic transformation of the Human World. Exeter: Imprint Academic, 2010.

4. Brink, A., Bruns, D., Strategies for Enhancing Landscape Architecture Research, Landscape Research, 2012.

5. Corner, J., Terra fluxus, The Landscape Urbanism Reader, 2006.

6. Corner, J., Landscape urbanism in the field. Topos 71, Landscape urbanism. 2010. p. 26.

7. Desimini, J., Wild Innovation: Stoss in Detroit by Published in Scenario 03: Rethinking Infrastructure, 2013.

8. Donadieu, P., Sciences du paysage. Entre théories et pratiques. Edition : LAVOISIER, 2012.

9. Etteger, R., Thompson, I.H., Vicenzotti, V. Aesthetic creation theory and landscape architecture, Journal of Landscape Architecture, 2016, Vol. 1, No. 1, , p. 80-91.

10. Gražulevičiūtè-Vileniškè, I., Gamta mieste: tyrimų problematika, Miestų želdynu formavimas, 2016, Vol. 1, No. 13 p. $99-111$

11. Jankevica, M., Comparative analysis of methodologies for landscape ecological aesthetics in urban planning. Science: Future of Lithuania, 2102, Vol. 4, No. 2, p. 113-119.

12. Jankevica, M., Evaluation of landscape ecological aesthetics of green spaces in Latvian large cities. Science: Future of Lithuania, 2013, Vol. 5, No. 3, p. 208-215.

13. Jauslin, D., Architecture with Landscape Methods. Doctoral thesis proposal and SANAA Rolex Learning Center Lausanne Sample Field Trip, Delft University of Technology, 2010.

14. Leger-Smith, F.-A., Evolution des pratiques des paysagistes face aux enjeux écologiques de la conception urbaine. Doctoral thesis, 2014.

15. Lifang, Q., Yichuan, Z., Wei, C., Evaluation of urban river landscape design rationality based on AHP, Water Science and Engineering, 2008, Vol. 1, No. 4, ISSN 1674-2370, p. 75-81

16. Lynch, K., Image of the city. Cambridge, Massachusetts, MTI Press, 1960.

17. Kalenda, Č., Ekologine etika: kilmé, principai, taikymas, Problemos, 2005, No. 68, ISSN 1392-1126, p. 135-147.

18. Kaplan, R., Kaplan, S., Brown, T., Environmental preference: A comparison of four domains of predictors. Environment and Behavior, 1989, Vol. 21 No. 5, p. 509-530.

19. Marot, S., L'alternative du paysage, Le visiteur, 1995, No. 1

20. Maslow, A., A theory of human motivation, Psychological Review, No. 50, 1943, p. 370-396.

21. Morin, E., La méthode (vol.1). La nature de la nature, Seuil, Paris, 1980.

22. Mostafavi, M., Najle, C., Landscape Urbanism: A Manual for the Machinic Landscape, AA Publications, 2004.

23. Nassauer J.I., Landscape as medium and method for synthesis in urban ecological design. Landscape and Urban Planning. Vol. 106, 2012, p. 221-229

24. Ode, Å., Tveit, M.S., Fry, G. Capturing Landscape Visual Character Using Indicators: Touching Base with Landscape Aesthetic Theory, Landscape Research, 2008, Vol. 33, No. 1, p. 89-117.

25. Saaty, T.L., Decision making with the analytic hierarchy process, Int. J. Services Sciences, 2008, Vol. 1, No. 1

26. Stamps III, A.E., Mystery, complexity, legibility and coherence: A meta-analysis, Journal of Environmental Psychology, 2004, No. 24, p. 1-16.

27. Stobbelaar, D.J., Pedroli, B., Perspectives on Landscape Identity: A Conceptual Challenge, Landscape Research, 2011, Vol. 36, No. 3, p. 321-339.

28. Stonkuvienė, I., 2004. Asmens ir gamtos santykiai kaimo bendruomenės požiūriu. Acta Pedagogica Vilnensia, 2004, No. 12, ISSN 1392-5016, p. 183-197.

29. Thompson, I.H., Aesthetic, Social and Ecological Values in Landscape Architecture: A Discourse Analysis, Ethics, Place \& Environment, 2000, p. 269-287

30. Waldheim, Ch., On Landscape, Ecology and other Modifiers to Urbanism. Topos 71, Landscape urbanism, 2010.

31. Waldheim, Ch., Introduction: landscape as architecture. Studies in the History of Gardens \& Designed Landscapes, 2014, Vol. 34, No. 3, p. 187-191,

32. Veinberga., M, Zigmunde, D., Aesthetics and Ecology in Planning of Urban Green Spaces of Latvia. Landscape Architecture and Art. Scientific Journal of Latvia University of Agriculture, 2016, Vol. 8, No. 8, p. 43-52.

33. Veteikis, D., Jukna, L., Jankauskaitė, M., Kraštovaizdžio struktūros pokyčiu probleminiuose arealuose vertinimas vietiniu lygmeniu, Ataskaita, 2015.

34. Vveinhardt, J., Gulbovaitė, E., Poreikių hierarchijos koncepcinis pagrịstumas nacionaliniame vertybių kongruencijos kontekste, Kultūra ir visuomene. Socialiniu tyrimu žurnalas, Vol. 4., No. 2., ISSN 2029-4573, 2013.

35. Zaleskienė E., Kamičaitytė-Virbašienė J., Gražulevičiūtė-Vileniškẻ I. Aesthetic aspects of landscapes in the ruralurban interface zones. Acta Biol. Univ. Daugavp., 2013, Vol. 13, No. 1, p. 173 - 188. 
INFORMATION ABOUT AUTHOR:

Vaiva Deveikiene, Vaiva Deveikiene, PhD at the Department of Urban design, Faculty of Architecture, Vilnius Gediminas Technical University, 26 Pylimo str. Vilnius, Lietuva, LT-03227. E-mail vaiva.deveikiene@vilnius.lt

Kopsavilkums. Pētījums veikts Lietuvā, Viḷnas pilsētā par dabas pamatnes un pilsētvides savstarpējo mijiedarbību un ainavu arhitektūras principiem, kas spēj nodrošināt kvalitatīvu pilsētvidi. Raksts ietver analīzi par ilgtspējīgas pilsētas attīstību, kur piemērojot atbilstošas metodes un principus, tiek pētìtas pilsētas ekolog̣iskās, estētiskās un sociāli funkcionāāās vajadzības, savstarpēji optimāli saskaņojot tās un izvērtēti dažādi pētījumā izvirzìtie kritēriji. Rakstā apkopoti pētījumā iegūtie rezultāti, kas nosaka ainavu arhitektūras un pilsētvides mijiedarbības kvalitāti un specifiku, attiecībā uz optimālajām mijiedarbības pētīšanas metodēm, izteiksmes rādīiājiem un vērtēšanas kritērijiem. 